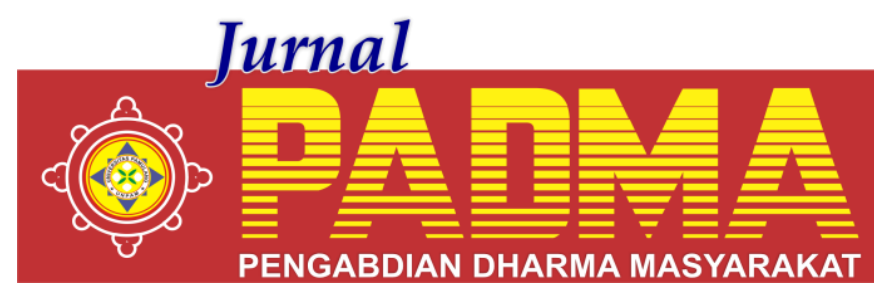

VOLUME 1, NOMOR 3, JULI 2021

\title{
MENABUNG SEJAK DINI AGAR SUKSES MERAIH MIMPI BAGI ANAK-ANAK DI TAMAN BACAAN PERIGI SAWANGAN
}

\author{
${ }^{1 *}$ Arief Budi Santoso, ${ }^{2}$ Agung Apriyuda, ${ }^{3}$ Ananda Dianti, ${ }^{4}$ Hanisa, \\ ${ }^{5}$ Monica Mega Pertiwi, ${ }^{6}$ Puri Widhi Hastuti \\ Universitas Pamulang, Tangerang Selatan, Banten, Indonesia \\ *dosen01152@unpam.ac.id
}

\begin{abstract}
Abstrak
Pengabdian masyarakat ini bertujuan mengedukasi sekaligus memotivasi anak untuk menggunakan uangnya secara benar serta memotivasi anak untuk gemar menabung agar masa depan yang lebih baik. Menabung sudah mulai ditanamkan sejak dini oleh beberapa orang tua kepada anaknya, karena tabungan memiliki peranan penting dimasa depan. Menabung yang berarti menyisihkan sebagian uang yang kita miliki untuk disimpan dan merupakan salah satu cara untuk mengelola uang. Kegiatan dilakukan di Taman Bacaan Perigi di Sawangan pada Sabtu, 13 Februari 2021 dan metode kegiatan ini melalui tahapan sosialisasi, mengajarkan anak-anak secara langsung, menggunakan bahasa dan cara yang menyenangkan sesuai dengan tingkat usia mereka, serta membuat celengan dengan menggunakan bahan daur ulang
\end{abstract}

Kata Kunci: Sosialisasi, Menabung, Keuangan

\section{Abstract}

This community service aims to educate as well as motivate children to use their money properly and motivate children to like to save for a better future. Some parents have started to invest in savings early in their children, because savings have an important role in the future. Saving means setting aside some of the money we have to save and is a way to manage money. The activity was carried out at the Perigi Reading Gardens in Sawangan on Saturday, February 13, 2021 and the method of this activity was through socialization stages, teaching children directly, using language and fun ways according to their age level, and making piggy banks using recycled materials.

Keywords: Socialization, Saving, Finance

\section{PENDAHULUAN}

Indonesia sendiri masih sangat jarang sekali memiliki lembaga pendidikan yang fokus pada pengetahuan dan keterampilan mengelola keuangan, tidak adanya kurikulum khusus tentang pendidikan keuangan di sekolah atau lembaga pendidikan non formil lainnya. Edukasi keuangan yang berisi motivasi untuk mengelola uang dengan baik, menabung dengan giat baik di lingkungan keluarga maupun sekolah masih belum dilakukan dengan serius dan terencana. Masyarakat kita juga terkenal tabu jika anak-anak membicarakan uang karena dianggap masih belum dewasa padahal pengetahuan dan keterampilan mengelola keuangan harus baik dan dibiasakan sejak kecil agar terbiasa hingga dewasa mampu mengambil keputusan yang benar untuk menggunakan uangnya.

Adanya keterbatasan pengetahuan dan perilaku masyarakat kita dalam mengelola keuangan pribadi, sehingga berdampak pada literasi keuangan menjadi tidak penting sebagai bekal untuk hidup dan masa depan anak. Tingkat literasi keuangan remaja masih sangat rendah, pola hidup lebih hedon dan konsumtif, tidak mampu mengelola keuangan dengan bijak menjadi perilaku dominan kehidupan remaja saat ini. Mereka juga tidak memiliki tabungan yang aktif, uang saku dihabiskan untuk gaya hidup, menabung bukan menjadi pilihan utama dalam menggunakan uang pribadi sehingga menjadi gambaran dan alasan penting untuk melakukan edukasi sekaligus memotivasi anak-anak sejak kecil agar mereka gemar dan giat menabung, mennggunakan uang 
saku secara bijak hingga terbiasa nanti saat dewasa akhirnya memiliki perilaku keuangan yang positif.

\section{METODE}

Metode dalam pengabdian kepada masyarakat ini merupakan metode eksperimen kegiatan yang digunakan kepada peserta setelah diberikan pelatihan, selanjutnya mereka akan di berikan test guna mengetahui ke efektifan metode.

Tahap Pelaksanaan kegiatan ini, mulai dari tahap yang akan menjelaskan tentang bagaimana pentingnya menabung sejak dini dan membiasakan diri untuk berhemat. Untuk melaksanakan kegiatan ini digunakan beberapa metode pelatihan, yaitu : Metode Penyuluhan dan Metode Simulasi

\section{HASIL DAN PEMBAHASAN}

Anak usia dini perlu diberi pemahaman menabung sangatlah penting dan mengajarkan kepada mereka bahwa menabung harus menjadi kebiasaan yang wajib dilakukan. Dengan mengajarkan cara seperti itu, maka kita telah mengajarkan mereka bahwa menabung merupakan hal yang penting yang harus dilakukan sejak dini. Mengajari mereka untuk menghargai uang yang mereka peroleh bahwa uang harus dihargai dan menjauhkannya dari sifat menghambur-hamburkan uang.

Mengajarkan menabung pada anak usia dini tidak perlu berpatokan pada nominal, melainkan terhadap konsistensi dan memotivasi agar anak kelak lebih giat menabung.

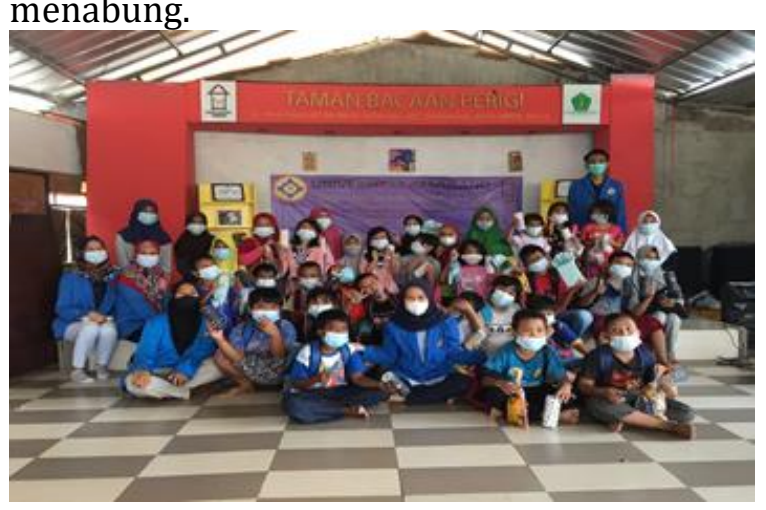

Gambar 1. Foto Bersama Panitia PKM
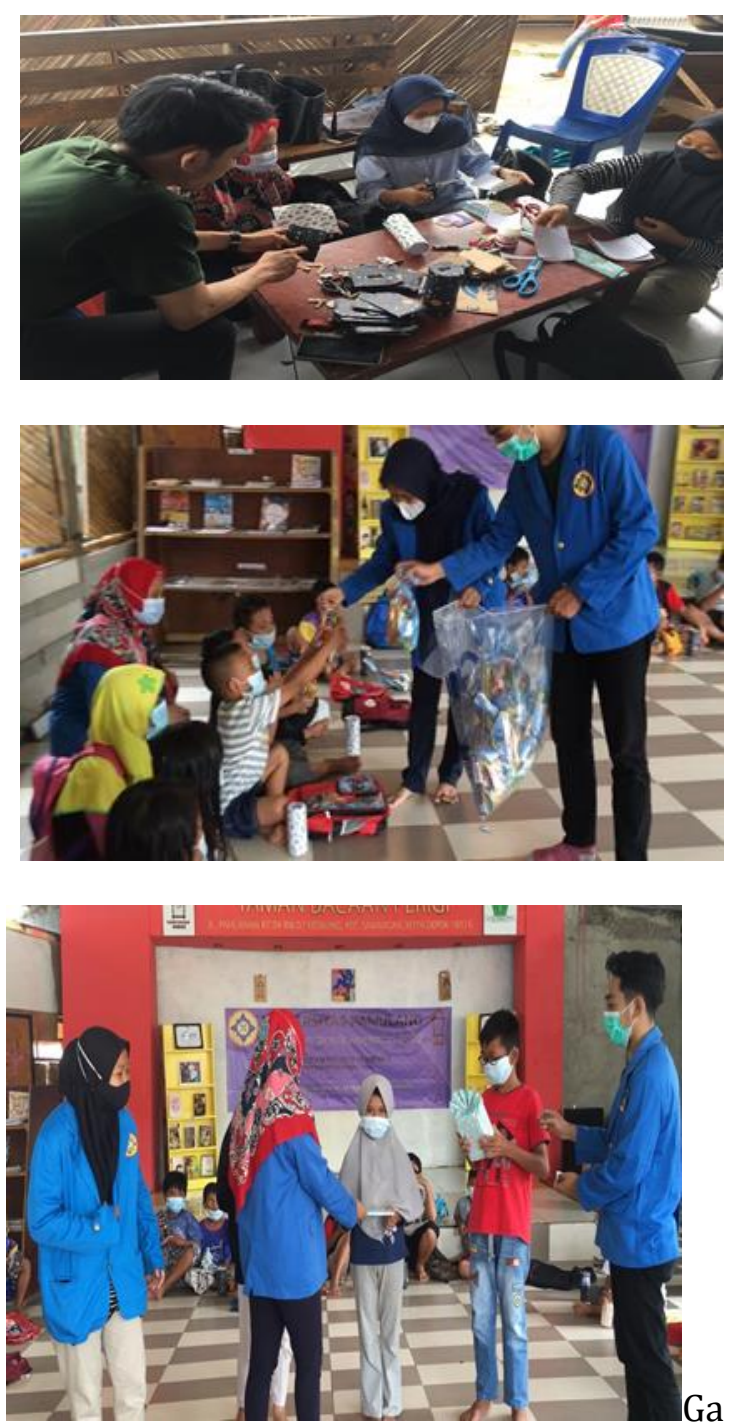

mbar 2. Aktivitas selama PKM

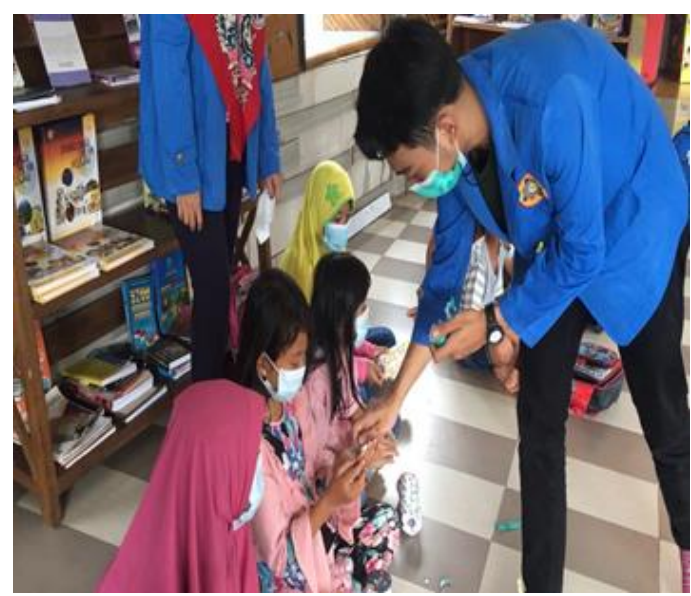

Gambar 3. Pemberian Cinderamata Kepada Peserta PKM 
PENUTUP

\section{KESIMPULAN DAN SARAN}

Pengabdian kepada masyarakat ini dilakukan di lingkungan Taman Bacaan Perigi dalam bentuk sosialisasi secara langsung namun tetap memperhatikan protokol kesehatan. Dengan mendidik dan mengenalkan anak cara mengelola keuangan yang baik, maka anak-anak akan tumbuh menjadi pribadi yang lebih menghargai uang serta pada kesempatan ini juga disimulasikan jika bahan-bahan bekas yang ada disekeliling mereka dapat dimanfaatkan untuk membuat celengan yang unik dan menarik sebagai media menabung

\section{DAFTAR PUSTAKA}

Ajimat, A., Sunarsi, D., \& Sidiq, F. (2020). Berwirausaha Memanfaatkan Media Sosial Pada Daerah Sepatan. ADI Pengabdian Kepada Masyarakat, 1(1), 69-76.

Akbar, I. R., Sunarsi, D., Salami, M. M., Sarwani, S., \& Catio, M. (2021). Peningkatan Minat Wirausaha Pada Siswa SMK Muhammadiyah Parung Kabupaten Bogor. Jurnal PADMA: Pengabdian Dharma Masyarakat, 1(2).

Dewanti, R. N., Supriyadi, E., Sofyan, S., Sunarsi, D., Rachmansyah, B. A., \& Yani, A. (2021). Penyuluhan Dan Pelatihan
Keterampilan Sablon Pigment Pasta Manual Di Karang Taruna 03 Desa Cisauk. Jurnal PADMA: Pengabdian Dharma Masyarakat, 1(1).

Liputan6.com, "Cara Membuat Celengan dari Botol Bekas Air Mineral, Ikuti 4 Langkah Mudah Berikut", 27 Juni 2020, $<$ https://hot.liputan6.com/read/4290 143/cara-membuat-celengan-daribotol-bekas-air-mineral-ikuti-4langkah-mudah-berikut> [diakses pada 25 Januari]

Paeno, P., Kasmad, K., Sunarsi, D., Maddinsyah, A., \& Supiyan, D. (2020). Pemanfaatan Sampah Plastik Untuk Kerajinan Rumah Tangga Taman Belajar Kreatif Mekar Sari. BAKTIMAS: Jurnal Pengabdian pada Masyarakat, 2(1), 57-61.

Seputar Pengetahuan, "Pengertian Menabung, Macam, Tujuan, Manfaat dan Tipsnya Lengkap" Agustus 2019, $<$ https://www.seputarpengetahuan.co. id/2019/08/menabung.html> [diakses pada 25 Januari 2021]

Superyou.co.id, "Selain Sukses, Ini 5 Manfaat Menabung Sejak Usia Dini", 29 May 2020,

$<$ https://superyou.co.id/blog/keuanga n/manfaat-menabung-anak/> [diakses pada 25 Januari 2021]. 